\title{
Swimming on Land: Some Suggestions for Today's Public Administration
}

\author{
Lihi Lahat ${ }^{1}$ \\ Published online: 9 October 2017 \\ (C) Springer Science+Business Media, LLC 2017
}

\begin{abstract}
In recent decades researchers have suggested various models for public administration organizations. These models and reforms, generally called New Public Management and Post-New Public Management, ignore the different developmental phases of public organizations, especially when dealing with non-Western countries. Instead of asking how public organizations should look, we suggest asking what should they do? To answer this question, we present several principles on the individual and organizational levels that can serve as a good compass for public managers. On the individual level, we maintain that public employees should focus on listening, helping and learning. On the organizational level, we advocate incorporating public policy with public administration, embracing core principles as opposed to trying to achieve ends, and returning public administration to its key role. These principles reinforce each other and thus can enhance the capability of public organizations.
\end{abstract}

Keywords Public administration · Principles $\cdot$ Public employees

\section{Introduction}

Researchers have been exploring different models and ideas to define public administration. Some of them call for redefining the boundaries and basic assumptions of public administration. For example, Koppell (2010) claims:

To thrive in 2020, we must conceive of the field of public administration in the broadest possible terms. Phenomena that typically have been treated peripherally in our literature are emerging center stage in recent years, confirming that the "old" boundaries of our discipline do not reflect contemporary reality (p. 546).

Lihi Lahat

lahat_1@mail.sapir.ac.il

1 Department of Public Administration \& Policy, Sapir College, M. P. Hof, 79165 Ashkelon, Israel 
Others suggest different models and strategies that reflect the next generation of public administration following the Weberian model and the New Public Management (see for example: Dunleavy et al. 2006; Pollitt and Bouckaert 2011; Stoker 2006). However, no single coherent model has emerged that dominates the current discourse.

In his retrospective on Simon's works, Meier (2014) notes the need for public administration to "achieve the twin goals of scientific validity and practical relevance" (p. 20). Given this sense that our discipline needs a new direction (Peters and Pierre 2016) this article tries to suggest a new perspective that emphasizes practical matters by suggesting several principles. We maintain that public employees should do three things: listen, help and learn. These three basic ideas can guide the actions of every public administration employee and manager. These goals require us not to find other solutions and design new models for public administration but to explore our actions in a new way. Furthermore, these three principles require complementary directions on the organizational level that improve the connection between public policy and public administration, create an institutional framework that can guide the actions of public administration and returns the public administration's organization to the center of activities. The current article explores these ideas in two phases. We begin with explanations about implementing the first three ideas at the employee level and then explore the other three goals at the organizational level. The final part connects the two together. However, the reader should bear in mind that these are exploratory suggestions that require further consideration.

\section{Swimming on Land}

Rapid changes in the nature and complexity of social problems, combined with more diverse populations and a reduced number of resources, have challenged public administrations worldwide (Beck 1992; Gregory 2015; Hajer 2003; Head and Alford 2015; Kondrasuk 2004; Richards and Smith 2002). Efforts to cope with these challenges were reflected in the New Public Management and Post-New Public Management reforms (Cohen 2016; Gray \& Jenkins 1995; Homburg et al 2007; Jones \& Kettel 2003), but it seems that the challenges are still with us. Rather than walking on land as we once did, we must now swim on land, meaning, we must work faster and adjust ourselves to the new flow to find creative solutions to various social problems (Dyer and Shafer 2003). Scholars have proposed various approaches to these issues, including among others, public value management, neo-Weberian models, new public governance and digital era governance (Dunleavy et al. 2006; Pollitt 2007; Pollitt and Bouckaert 2011; Stoker 2006). However, we maintain that a different question should guide our search for solutions - what should public administration organizations do?

Approaching the issue from this vantage point is beneficial, because it allows public organizations in different developmental stages to evolve in accordance with their capabilities. Furthermore, it may be more fruitful for public organizations in countries other than those in the Western world that are the focus of the literature (Ferlie and Ongaro 2015: 128; Pollitt 2007; Pollitt and Bouckaert 2011). Given the wide range of stages of development in public organizations and their varying cultural contexts, trying to suggest a coherent model of public administration is problematic at best.

Public administration employees usually picture themselves in terms of their profession: social workers, teachers or police officers (Lipsky 2010: 216). However, they are all public employees who serve the public (Shafritz et al. 2009). This unique function demands that beyond their professional and managerial expertise, they also share various personal 
characteristics. Studies have shown that public employees are more trustworthy, publicspirited, motivated to serve the public and altruist than others (Ghorpade et al. 2001; Perry 2012; Van de Walle and Lahat 2016). Therefore, suggesting actions that public employees can take seems a useful framework for public administration.

\section{A Vision for Public Officials}

\section{Listen}

One of the unique characteristics that public employees need is the ability to listen. Only by cultivating this ability can they respond to the needs of the citizens they serve, their partners and other stakeholders that are part of the public administration. This trait corresponds with the need to be more responsive to citizens and promotes collaboration in the era of collaborative governance (Ansell 2012; Ansell and Gash 2008; Emerson et al. 2012; Vigoda-Gadot 2009). In addition, it is an ability that is needed for managers and support units inside the government hoping to improve the way they work. Furthermore, it accords with the growing understanding that government organizations operate in structures of networks (Bevir 2012; Klijn 2010; Koppenjan and Klijn 2004; O'Toole and Meier 2010). This quality is required when people want to cooperate with others. It should be emphasized that listening does not mean that one should accept all of the perceptions and demands of various stakeholders. Instead, it refers to the ability to engage in a true and open dialogue.

This suggestion is in line with the ideas grounded in the idea of interpretative governance (Rhodes 2012), an approach that seems to be gaining ground in public policy (Stone in van Ostaijen and Jhagroe 2015). The "awareness of our unawareness," as Hajer (2003) says, expresses the importance of the ability to actively engage in listening to different voices. Listening, therefore, can enhance the ability to be a central actor in the multifaceted structure of governance.

\section{Help}

Government and its organizations exist primarily to promote the public interest and help people achieve a degree of well-being that they cannot achieve on their own (Vigoda-Gadot and Mizrahi 2014). Nevertheless, the definition of needs is not a simple one and depends on culture, norms and perceptions of societies, and interpretations by actors in the political process (Stone 2012). Thus, at its core public organizations must help individuals meet their needs and realize their aspirations (Lipsky 2010: 229). Of course, that there are limitations to the ability of public organizations to intervene in people's lives. These limitations are rooted in ideological reasons (the role of the state) and practical reasons (administrative limitations, political realities and limited resources). However, the notion that this is the essence of the work is important to promoting principles such as responsiveness, participation and citizen-centered services. One can claim that in many ways public organizations' actions favor the general welfare over specific sections of the population (Dery 1996; Wamsley and Zald 1973) and may not win the approval of all (Rhodes and Wanna 2007: 409). Clearly, we limit individual freedom when incarcerating prisoners, drafting soldiers and collecting taxes. Meier and Hill (2005: 58) explain that the client-driven orientation is problematic when dealing with people such as felons who have a negative stereotype. 
Nevertheless, we are still bound to find ways in which we can help and strike a balance between helping them as well as other sectors of society. Thus, bearing in mind the idea of helping, we must ask whom we are helping, why, and how? These important questions can keep public organizations focused on their values and the reasons behind their actions (Stoker 2006). The ability to answer these questions may improve the accountability of public administration and reduce the tendencies of professionals and organizations to focus on routines and their own interests (Blau and Meyer 1971; Downs and Rand Corporation 1967) and minimize bureaucratic failures (Weimer and Vining 2004).

\section{Learn}

The rapid changes in today's world require us all to become constant learners. Public employees should embrace a passion for learning, asking questions about trends and changes in their surroundings, the changing nature of the needs of the population they serve, and the new methods they can apply to improve their work. To become a learner, public officials must be both brave and cautious. While these traits seem to be contradictory, we maintain that both are necessary for incorporating learning opportunities into the administrative culture. Being brave is the ability to cope with the fear involved in change. Putting new procedures in place will not necessarily result in positive outcomes (Van Buuren 2009). The only way to learn is to be brave enough to try. At the same time, knowing that they are being held accountable for their actions makes public officials fearful about being wrong (Mulgan 2000: 567). Therefore, they may be inclined to avoid change to minimize being criticized. Blau and Meyer (1971) explain, "Rigid adherence to the established routine is a defense mechanism against feelings of insecurity" (p. 104). Nevertheless, this behavior in a constantly changing environment is at least problematic and often harmful. This pattern of behavior requires a different vision of society as well. Public administration must be given more room to maneuver. We will elaborate on this point further in the second section of the article.

The other characteristic is to be cautious. Although we cannot predict the outcomes of new approaches, we should do our best to plan them before implementing them (Shapiro 2016). The ability to predict potential outcomes is an important feature of our obligation to promote the public interest and to be accountable for public resources. The growing literature on policy learning (Dolowitz 2004), the notion of evidencebased policy and practice as well as strategic management are part of these trends (Davies et al. 2000; Ferlie and Ongaro 2015; Freeman and Sturdy 2014). We maintain that, while recognizing that we cannot control all of the variables that affect policy outcomes, public administration is advised to be brave as well as cautious in confronting issues and adopting new ideas.

\section{The Three Paths for Today's Public Administration Organizations}

Individuals do not operate on their own, and public employees work in the organizational context. Thus, the dance between individuals and the organization is an important one. Discretion is an important element in the work of many public employees, requiring them to strike a balance between the needs of their citizen and the organization's interests, actions and preferences. Therefore, we should strengthen three areas in public administration to create an environment that encourages this balance. 


\section{Public Policy and Public Administration: a United Front}

Public administration and public policy are two sides of the same coin (Shafritz et al. 2009). However, a review of the literature as well as of practice seems to hint that the two are not sufficiently connected and are often more separate than united. Most researchers identify themselves as public administration researchers or public policy researchers. Different journals have different focuses, and although there is some association between the two fields (Pollitt 2016: 15), it seems that in practical terms the awareness that there should be a stronger connection between the two is not prominent. As Moynihan and Soss (2014: 5) claim: "The key point is that students of administration have largely ignored the role of policy in this process".

Various perspectives on strategic management have different visions and goals for the organization and focus on the steps needed to achieve those goals (Ferlie and Ongaro 2015). However, they often do not emphasize the design of policy at the macro, mezzo and micro level. Policy seems to be the purview of the central government, while the other branches of public organization are expected to follow the policy and find ways to implement it. For example, Rhodes and Wanna (2007) criticize the call for more value oriented public management due to its inappropriateness especially for the Westminster model. However, looking at different implementation studies, it seems that policy is being decided at the different levels without being characterized as such. For example, when a group of professionals decide on implementing a program for a specific target population, they are in fact creating a mezzo level policy for this group. Street-level studies have demonstrated that the policy itself is created in these encounters with citizens in various ways (Brodkin 2011; Cohen and Gershgoren 2013; Lipsky 2010). Lipsky (2010) emphasizes that it should be interpreted in the context of the macro policy and not as a self-preserving policy (p. 221). Nevertheless, according to one of the known definitions of public policy articulated by William Jenkins (1978) as "a set of interrelated decision taken by a political actor or group of actors concerning the selection of goals and means of achieving them within a specified situation where those decisions should, in principle, be within the power of those actors to achieve" (in Howlett and Ramesh 2003: 6), they design public policy. The changing structure of governance via network governance and collaborative governance reflects the growing persistence of policy design at different levels. These policies should be devised in conjunction with the macro policy. Nevertheless, the design of policy on different levels is more prevalent in current public administration. Managers in public organizations not only engage with other stakeholders to be suppliers of public services. They also work on designing policies that are connected to and influenced by the organizational context and surroundings involved in those processes.

The idea that public administration should serve and adapt to policy goals is often not prominent. In many cases, it seems hard to achieve the goals of the policy, because the structures of public administration are not conducive to promoting the policy goals. Furthermore, public officials who design policy at the mezzo level do not understand it as a kind of policy. They embrace the limitations of the organizational structure and put less emphasis on the need to change the organizational structure to realize the goals of the policy.

\section{The Core and the Ends}

The last four decades have moved between the contradictory trends of decentralization and fragmentation versus centralization and integration. On the one hand, decentralization, which 
figured prominently in the NPM reforms, aimed at bringing services closer to the target populations and dismantling the complexities and inefficiency of the hierarchical decisionmaking process. On the other hand, it fragmented organizational structures and created inequality between different users, resulting in the post-NPM reforms that called for integration and unification (Christensen et al. 2014; Dunleavy et al. 2006; Dommett et al. 2016; Rhodes 2000). The pros and cons of these contradictory processes are part of a long-standing dialogue aimed at balancing the two (Metcalfe and Richards 1987: 78-79).

How can we create better equilibrium between the need for unification on the one hand and the need for decentralization on the other? One solution is to create core principles and differentiate between branches (Rhodes 2012: 37), much like a fish skeleton whose bones spread out from a central spine. The various agencies can define the core principles that should be embraced by their sub-agencies and then determine which of them is responsible for achieving specific goals. The core principles describe the basic values, not just the outcomes to be achieved. This framework provides control and unification on the one hand and diversity on the other. Examples such as social regulation (Braithwaite 2002) and educational policies in the case of learning disabilities (Itkonen and Jahnukainen 2010) reveal that creating core principles but allowing room to maneuver that reflects meaningful discretion results in better policy outcomes.

The attempts so far to achieve command and control via the specification of rules and procedures seem problematic. The other extreme of decentralization has found it difficult to create a variety of goods and services, leading to gaps and inequality. Thus, embracing the idea of defending core principles for working in public organizations is more likely to create equilibrium.

\section{Bring Back Public Administration}

Recent reforms in public administration have weakened the place of government organizations. Trends such as the hollowing out of the state (Rhodes 1994) and network governance (Bevir 2012) brought different stakeholders into government actions and in many respects impaired the central role of public administration organizations as the leading player in providing goods and services to the citizens. While including various stakeholders in the design of policy and the delivery of public services is important, the place of the state as a central actor should not be overlooked (Pierre and Peters 2005). Therefore, we underscore the need to bring public administration back as a key element in the equation, because it embodies the primary goal of promoting the interests of the citizens. Just as Flinders (2012) calls on us to defend politics, we should defend the central place of public administrations in the web of today's stakeholders.

Public administration should not see its role as simply coping with problems but as defining and pursuing the values that benefit societies (Stoker 2006). Although it may seem trivial to say so, doing so is more controversial and complicated to implement (Hartley et al. 2015; Rhodes and Wanna 2007). Furthermore, given the difficulties and problems that overwhelm public employees, few have time to ask, what do we really want to accomplish. We should trust public employees and give them the opportunity and discretion to develop the vision they want to pursue. Of course, this vision should accord with the broad values and macro policy reflecting the political preference of the elected officials. 
While this discretion should not be unchecked, the NPM atmosphere has created the tendency to distrust public employees. Discretion goes hand with hand with trust. Therefore, we must bring public employees back to the center of attention and rebuild their sense that we trust them. Doing so is an important factor in improving the outcomes of public organizations (Bouckaert 2012; Brown and Calnan 2011; Itkonen and Jahnukainen 2010).

\section{Conclusion: the Incorporation of the Individual and the Organizational Level}

Figure 1 illustrates the nexus between the characteristics that we should cultivate in public employees and their interaction with the organizational structure. These suggestions at the individual and organizational level reinforce and depend one on another. The importance of listening on the individual level expresses the awareness that public administration creates policy. Policy in today's society involves many voices, so we need to listen to different stakeholders when creating mezzo level policies in public organizations.

The need to help people emphasizes the understanding that public employees should be trusted to do their work. The creation of structures that define core principles and leave room for public employees to maneuver is once again the cause and the effect of this idea. Thus, if we accept that the main motivation of public employees is helping the public, we can have a more trusting relationship with them, give them more discretion in doing their jobs and believe that they will create core principles dedicated to this goal. In addition, using their discretion, they can tailor make solutions for people based on their individual needs, a goal that is quite desirable today. In so doing, they can provide equality of service without equating it with identical service for all (Du Gay 2011).

The importance of learning as a basic feature of the public employees' raison d'être is another aspect that accords with the fishbone metaphor of public organizations. If we agree that public employees should be constant learners, we can appreciate the contribution of discretion and the role of employees from different layers in public organizations. Furthermore, the core principles should be created based on understandings arising from different layers in the organization in an ongoing synthesis. Thus, the learning process is a collective process, not just an individual one (Heikkila and Gerlak 2013), resulting in an organizational culture that reflects "epistemological pluralism" that incorporates both implicit and explicit knowledge on the individual and social level (Spender 1996).

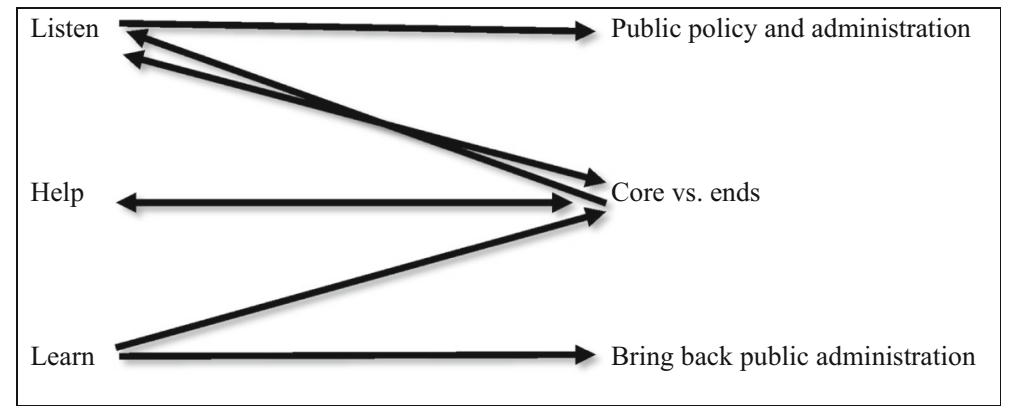

Fig. 1 The nexus between public employees and the organizational context 
At the same time, the learning of the individual public employee can enhance the ability of public organizations to become a central actor in the public arena. If authority and resources were the old basis of legitimizing public administration, today knowledge plays a central role in the policy process. In an age of accountability and transparency, resources are not the only factor of great importance. The ability to explain public administration is one of its major bases of legitimation. If public organizations do not perceive it as an important factor in the policy process, their ability to help the population is impeded, and in a vicious cycle, the path to improving public administration is blocked. The first step in this process is adopting a different view of public administration and a different focus on the factors that should be strengthened. Hopefully, the reasoning presented here can provide some opportunity for doing just that.

Funding This paper was not funded by a grant

\section{Compliance with Ethical Standards}

Conflict of Interest Although my academic position the paper was inspired by a previous experience (June 2013-December 2014) in the Ministry of Social Services and Social Affairs in Israel. I wrote the paper after this experience and I declare that I have no conflict of interest.

Ethical Approval This article does not contain any studies with human participants or animals performed by any of the authors.

\section{References}

Ansell, C. (2012). Collaborative governance. In D. Levi-Faur (Ed.), The Oxford handbook of governance (pp. 499-511). New York: Oxford University Press.

Ansell, C., \& Gash, A. (2008). Collaborative governance in theory and practice. Journal of Public Administration Theory and Practice, 18, 543-571.

Beck, U. (1992). Risk society: towards a new modernity, 17. Thousand Oaks: Sage.

Bevir, M. (2012). Governance: a very short introduction. Hampshire: Oxford University Press.

Blau, P. M., \& Meyer, M. (1971). Bureaucracy in modern society (2nd ed.). New York: Random House.

Bouckaert, G. (2012). Trust and public administration. Administration, 60, 91-115.

Braithwaite, J. (2002). Restorative justice \& responsive regulation. Oxford: Oxford University Press on Demand.

Brodkin, E. Z. (2011). Policy work: street-level organizations under new managerialism. Journal of Public Administration Research and Theory, 21, i253-i277.

Brown, P. R., \& Calnan, M. (2011). The civilizing process of trust: developing quality mechanisms which are local, professional-led and thus legitimate. Social Policy \& Administration, 45, 19-34.

Christensen, T., Fimreite, A., \& Lægreid, P. (2014). Joined-up government for welfare administration reform in Norway. Public Organization Review, 14, 439-456.

Cohen, N. (2016). Forgoing new public management and adopting post-new public management principles: the on-going civil service reform in Israel. Public Administration and Development, 36, 20-34.

Cohen, N., \& Gershgoren, S. (2013). The incentives of street-level bureaucrats and inequality in tax assessments. Administration \& Society, 48, 267-289.

Davies, H. T. O., Nutley, S. M., \& Smith, P. C. (Eds.). (2000). What works? Evidence-based policy and practice in public services. Bristol: Policy Press.

Dery, D. (1996). Introduction to public administration. Israel: The Open University of Israel (in Hebrew).

Dolowitz, D. P. (2004). Bring back the states: correcting for the omissions of globalization. International Journal of Public Policy and Management, 29, 263-280.

Dommett, K., MacCarthaigh, M., \& Hardiman, N. (2016). Reforming the Westminster model of agency governance: Britain and Ireland after the crisis. Governance, 29, 535-552. 
Downs, A., \& Rand Corporation. (1967). Inside bureaucracy. Boston: Little, Brown.

Du Gay, P. (2011). Without regard to person': problems of involvement and attachment in 'post bureaucratic' public management. In S. R. Clegg, M. Harris, \& H. Hopfl (Eds.), Managing modernity: beyond bureaucracy? (pp. 11-29). Oxford: Oxford University Press.

Dunleavy, P., Margetts, H., Bastow, S., \& Tinkler, J. (2006). New public management is dead-long live digital-era governance. Journal of Public Administration Research and Theory, 16, 467-494.

Dyer, L., \& Shafer, R.A. (2003). Dynamic organizations: achieving marketplace and organizational agility with people. (CAHRS Working Paper \#03-04). Ithaca: Cornell University, School of Industrial and Labor Relations, Center for Advanced Human Resource Studies. http://digitalcommons.ilr.cornell. edu/cahrswp/27/CornellUniversity

Emerson, K., Nabatchi, T., \& Balogh, S. (2012). An integrative framework for collaborative governance. Journal of Public Administration Research and Theory, 22, 1-29.

Ferlie, E., \& Ongaro, E. (2015). Strategic management in public services organizations: concepts, schools and contemporary issues. New-York: Routledge.

Flinders, M. (2012). Defending politics: why democracy matters in the twenty-first century. Oxford: Oxford University Press.

Freeman, R., \& Sturdy, S. (2014). Introduction: knowledge in policy-embodied, inscribed, enacted. In R. Freeman \& S. Sturdy (Eds.), Knowledge in policy: embodied, inscribed, enacted (pp. 1-20). Bristol: Policy Press.

Ghorpade, J., Lackritz, J., \& Singh, G. (2001). Work values and preferences for employee involvement in the management of organizations. Employee Responsibilities and Rights Journal, 13(4), 191-203.

Gray, A., \& Jenkins, B. (1995). From public administration to public management: reassessing a revolution? Public Administration, 73, 75-99.

Gregory, L. (2015). Trading time: can exchange lead to social change? Bristol: Policy Press.

Hajer, M. (2003). Policy without polity? Policy analysis and the institutional void. Policy Sciences, 36, $175-195$.

Hartley, J., Alford, J., Hughes, O., \& Yates, S. (2015). Public value and political astuteness in the work of public managers: the art of the possible. Public Administration, 93, 195-211.

Head, B. W., \& Alford, J. (2015). Wicked problems implications for public policy and management. Administration \& Society, 47, 711-739.

Heikkila, T., \& Gerlak, A. K. (2013). Building a conceptual approach to collective learning: lessons for public policy scholars. Policy Studies Journal, 41, 484-511.

Homburg, V., Pollitt, C., \& van Thiel, S. (2007). Introduction. In C. Poliitt, S. van Thiel, \& V. Homburg (Eds.), New public management in Europe. Hampshire: Palgrave.

Howlett, M., \& Ramesh, M. (2003). Studying public policy: policy cycles and policy subsystem (2nd ed.). Oxford: Oxford University Press.

Itkonen, T., \& Jahnukainen, M. (2010). Disability or learning difficulty? Politicians or educators? Constructing special education in Finland and the United States. Comparative Sociology, 9, 182-201.

Jones, L. R., \& Kettel, D. F. (2003). Assessing public management reform in an international context. International Public Management Review, 4(1), 1-19.

Klijn, E. H. (2010). Trust in governance networks: looking for conditions for innovative solutions and outcomes. In S. Osborne (Ed.), The new public governance?: emerging perspectives on the theory and practice of public governance (pp. 303-321). Abington and New York: Routledge.

Kondrasuk, J. N. (2004). The effects of $9 / 11$ and terrorism on human resource management: recovery, reconsideration, and renewal. Employee Responsibilities and Rights Journal, 16(1), 25-35.

Koppell, G. S. J. (2010). Administration without borders. Public Administration Review, Special Issue, 70, s46-s55.

Koppenjan, J. F. M., \& Klijn, E. H. (2004). Managing uncertainties in networks: a network approach to problem solving and decision making. London, New York: Routledge.

Lipsky, M. (2010). Street-level bureaucracy: dilemmas of the individual in public service (30th ann. ed.). NewYork: Russell Sage Foundation.

Meier, K. J. (2014). Proverbs and evolution of public administration. Public Administration Review, 75, 15-24.

Meier, K. J., \& Hill, G. C. (2005). Bureaucracy in the twenty - first century. In E. Ferlie, L. E. Jr Lynn, \& C. Pollitt (Eds.), The Oxford handbook of public management (pp. 51-72). Hampshire: Oxford University Press.

Metcalfe, L., \& Richards, S. (1987). Improving public management. Oxford: Sage.

Moynihan, D. P., \& Soss, J. (2014). Policy feedback and the politics of administration. Public Administration Review, 74, 320-332.

Mulgan, R. (2000). Accountability': an ever-expanding concept? Public Administration, 78, 555-573.

O'Toole, L. J., \& Meier, K. J. (2010). Implementation and managerial networking. In S. Osborne (Ed.), The new public governance?: Emerging perspectives on the theory and practice of public governance (pp. 322-336). Abington, New York: Routledge. 
Perry, J. L. (2012). Does making a difference make a difference? Answers from research on public service motivation. In G. Tria \& G. Valotti (Eds.), Reforming the public sector - how to achieve better transparency service and leadership (pp. 51-67). Washington D.C: Brookings Institution Press.

Peters, B. G., \& Pierre, J. (2016). Two roads to nowhere: appraising 30 years of public administration research. Governance, Early view. https://doi.org/10.1111/gove.12229.

Pierre, J., \& Peters, B. G. (2005). Governing complex societies: trajectories and scenarios. New York: Palgrave.

Pollitt, C. (2007). Convergence or divergence: what has been happening in Europe? In Pollitt C., Thiel S.V., \& Homburg V. (Eds.), New public management in Europe (pp. 10-25). Palgrave: Hampshire.

Pollitt, C. (2016). Advanced introduction to public management and administration. Cheltenham: Edward Elgar.

Pollitt, C., \& Bouckaert, G. (2011). Comparative public management reform: an introduction to the key debates. In C. Pollitt \& G. Bouckaert (Eds.), Public management reform: a comparative analysis (3rd ed., pp. 1-30). Oxford: Oxford University Press.

Rhodes, R. A. W. (1994). The hollowing out of the state: the changing nature of the public service in Britain. The Political Quarterly, 65, 138-151.

Rhodes, R. A. W. (2000). New labour's civil service: summing-up joining-up. The Political Quarterly, 71(2), 151-166.

Rhodes, R. A. W. (2012). Waves of governance (pp. 33-48) In D. Levi-Faur (Ed.), The Oxford Handbook of Governance. Oxford: Oxford University Press.

Rhodes, R. A. W., \& Wanna, J. (2007). The limits to public value, or rescuing responsible government from the platonic guardians. Australian Journal of Public Administration, 66, 406-421.

Richards, D., \& Smith, M. (2002). Introduction: public policy in changing world. In D. Richards \& M. Smith (Eds.), Governance and public policy in the UK (pp. 1-26). Oxford: Oxford Press.

Shafritz, J. M., Russell, E. W., \& Borick, C. P. (2009). Introducing public administration (6th ed.). New York: Pearson: Longman.

Shapiro, S. (2016). Analysis and public policy: successes, failures and directions for reform. Cheltenham: Edward Elgar.

Spender, J. C. (1996). Organizational knowledge, learning and memory: three concepts in search of a theory. Journal of Organizational Change Management, 9, 63-78.

Stoker, G. (2006). Public value management a new narrative for networked governance? The American Review of Public Administration, 36, 41-57.

Stone, D. A. (2012). Policy paradox: the art of political decision making. New York: WW Norton.

Van Buuren, A. (2009). Knowledge for governance, governance of knowledge: inclusive knowledge management in collaborative governance processes. International Public Management Journal, 12, 208-235.

Van de Walle, S., \& Lahat, L. (2016). Do public officials trust citizens? A welfare state perspective. Social Policy \& Administration. Early view. https://doi.org/10.1111/spol.12234.

Van Ostaijen, M., \& Jhagroe, S. (2015). Get those voices at the table!': interview with Deborah stone. Policy Sciences, 48, 127-133.

Vigoda-Gadot, E. (2009). Building strong nation. Fanham: Ashgate.

Vigoda-Gadot, E., \& Mizrahi, S. (2014). Managing democracies in turbulent times: trust, performance, and governance in modern states. Heidelberg: Springer Science \& Business Media.

Wamsley, G. L., \& Zald, M. N. (1973). The political economy of public organizations. Public Administration Review, 33, 62-73.

Weimer, D. L., \& Vining, A. R. (2004). Policy analysis: concepts and practice (4th ed.). New Jersey: Pearson Prentice Hall. 